\title{
INTERNSHIPS IN TOURISM AND HOSPITALITY: AN \\ ANALYTICAL STUDY OF THE IMPACT ON STUDENTS' \\ KNOWLEDGE AND SKILLS
}

\author{
MOHAMED S. GAD, EL-RAB \\ ALIAA M. EL-NAGAR \\ FACULTY OF TOURISM AND HOTELS, FAYOUM UNIVERSITY, EGYPT
}

\begin{abstract}
Tourism teaching plays an important role in supporting tourism development. It ensures the continuous supply of quality of human resources to meet the overpowering industry requirements. To channel the gap between students' academic experience and the requirements of employers, most of tourism and hotel academic enterprises provide internship agenda. The internship has become an essential component of almost all hospitality programs worldwide.

Internships support a real-work practices to students that looking for exploring or acquiring related to knowledge and skills required to be involved in a career area. Internships are of a relatively short term with the primary focus on getting some training and taking what has been learned in the theoretical lectures and applying it to the real world. The internship should be a chance for the students to gain entry to a certain establishment.

This research aims to examine the effect of internship agenda on students, knowledge, attitudes and skills. It explores the benefits and challenges of internships in the tourism and hospitality sector, and how these affect students' desire to work in the career in the future. The population of this study includes students of faculties of tourism and hotels in Nine public universities in Egypt.
\end{abstract}

KEYWORDS: Internships, Tourism, Hospitality, Egypt.

\section{INTRODUCTION}

Hospitality education is designed to educate people gaining professional knowledge and skills to enter the hospitality industry. In the hospitality courses, hospitality educators are challenged to teach technical skills and provide chances for a workable application for students to integrate their skills and information (Fu,1999; Yafang and Gongyong 2007).

Felicen et al. (2014) stated that the quality of education in hospitality 
establishments is one of the basic goals for development. The hospitality educational barriers is bridging the gaps between labor market requirements and the present acquired skills and offer educational training agenda needed by the workable experience. It is imperative; therefore, the industry and academic establishment should be integrated in the context of eliminating the gap between the industry need and the skills offered by the educational establishment.

As the connection and integrating between theoretical lectures learning and real- workable skills in the work environment has been recognized as a vital component of student engagement and development in higher learning so, one of how students may base their learning in the theoretical lectures with professional experiences is extensive labeled as student internships (Kuh,2008; Stirling et al.,2014).

Also, Shin etal.(2012) mentioned that the internship is planned to offer the a real experiences for students before graduation, it is an agenda for the students to trial the real environment in advance and it is also good to encourage them to study harder. Students are placed with a wide variety of supporting firms based on their areas of interest. Students are released from faculty for part of the faculty day or year; work a checkered number of required hours on a part-time foundation for a chosen time. The student receive on-the-job, work training from skilled professionals, who provide the information and expertise of their area. Students are evaluated by both their faculty coordinator and their work supervisor using a true, competency- and performance-assessment model (Merrit, 2008; Cheong, 2013).

So, Zopiatis and theocharous (2013) stated that hospitality internships are a critical part of almost all reputable hospitality program globally. Despite their universal recognition as a dynamic part of hospitality education, their value is often superseded by the challenges facing hospitality stakeholders in providing such an experience for the next generation of hospitality professions.

\section{LITERATURE REVIEW}

The importance of hospitality education has been realized worldwide for many years and hospitality education plays a major role in supplying skilled and experienced human. (Lam and Ching,2007). So, internships play a vital role in students, companies, and academic programs. Internships are valuable learning experiences for the hospitality and tourism industry. Both the industry and study programs should offer strengthening to internships and properly advise the next generation of workers. Internships should be practiced at faculties as a step in developing students into professionals; they can also deal with problems in today's businesses (Brandon, 2011). 
The internships significant is well documented in hospitality research literature (Morgan,2004). It provides real-work industry demands, enhance skills and update essential information to get used to the student to work passionately and in a team, move quickly, solving customer problems, and keep pace with the customer expectations. Therefore, to some, stepping back into the industry is a highly desired learning chance (Kimberly and Zhao, 2004).

Kobino and Neequaya (2014) and Akomaninga et al. (2011) stated that internships are a necessary condition for the students as tourism and hospitality education is a branch of technical education. Hence, the application of internships in the departments of tourism and hospitality is an critical subject which suffers from a large number of challenges and barriers faced by students according to stakeholders such as weak links between the educational institutions and the hospitality real-industry leading to the ineffective application they also suggested internship time to be extended, and industry's and teachers' active participation in an internship.

\section{INTERNSHIP DEFINITION}

Gower, (2008) defined internship as " It is a directed process aimed at linking the technical side to the participation in the planned work for university students ". He also defined internship as "Conveying workrelated practices that may students face outside the campus." Coordination and joint cooperation between the academic unit and the agency's supervisor determine the required internship ". As a result of being closely related to the academic specialization, the university may pay for internships, or offer an unpaid academic credit in diversified amounts ".(Jauhari 2009)

Internships aim to the exclusion of other academic groups through the student's practical participation in work-related experience, and this makes internships, or so-called group placements, full-time most often and which are usually acquired during undergraduates' final years". " (Ellis, 2010. (

" The internship develops the student's personal and professional skills and opens up prospects for him to develop the future career area and direct headmen to appreciate and take care of the talents through the flexible and planned transition from the university's academic environment to that of work, which is done by linking both theoretical materials and internship experience "( Corrales,2014).

San Diego State University (2014) San Diego State University (2014) defined internship as: "combining theoretical knowledge and principles with practical experiences in a professional way that leads to skills development. Internships allow students to acquire beneficial implied experience and link it to professional and functional scopes, and direct 
headmen to appreciate and take care of the talents ".

According to Career Center University of North Carolina Wilmington (2011), stated that the "internship is a form of experiential learning that integrates information and theory learned in the theoretical lectures with workable application and skill development in a professional setting. Students may earn study credit from a degree-granting, educational institution. The academic department within the declared specialization of the student supervise the internship through one of the faculty members. The internship, which may be part-time or full-time, paid, or unpaid, can be acquired through semester time. A learning agenda in the form of specific objectives are established before the start of the internship".

\section{FORMS OF INTERNSHIPS}

Kwon (2002) divides the internship into two types.

1- Academic internships: faculty suggest students standardized workable training and help them select the best internships based on their studies. Faculty also give academic credit, which is awarded based on the number of work hours, duties, or performances.

2- Non-academic internships are required by the student and usually organized between the student and the employer. If students cannot arrange an internship through the school and they are hopeful to work for a particular company after graduation, non-academic related internships are another choice although they cannot get any pay or academic credit.

The time of the internship should be agreed in advance before the internship starts with the exact starting and ending date stated in the agreement form. Though the time may vary from one company to another, the faculty offering the internship credit should be involved because most schools will have a lower number of hours of internship necessary for each credit got by the student. (Carlson and Halbrooks, 2003).

\section{FORMS OF INTERNSHIPS}

(1) Internship as part of a formal education agenda: An internship is an educational activity planned to gain competencies, skills, and attitudes for a qualification awarded at the end of the formal agenda. This includes work environments during faculty or professional training. ( Kari et al, 2014).

(2)An internship that takes place outside formal education: The intern freely develops on-the-job area to acquire skills according to his/her formal educational qualifications and needs. This is when young people 
work as interns salaried or free for a e while at a certain company or nongovernmental organization. (Mgaya and Mbekomize,2015)

\section{CHARACTERISTICS OF INTERNSHIPS}

National Association of Colleges and Employers (2011), U.S. Department of Labor Wage and Hour Division (2010), Shoenfelt (2012) mentioned that " Internship develop the student's personal and professional through the following challenging work assignments:

1. The internship includes experiences that match what is learned in the theoretical lectures.

2. The internship is completed either before graduation, or through the period between finishing the undergraduate degree and before starting a graduate degree program.

3. The internship includes actual operation of the employer's facilities which will be relatively close to training that would be given in the faculty.

4. The internship is arranged through the department and faculty in order to enhance the undergraduate`s experience.

5. The student usually works under the close observation of a regular employee.

6. Internship is based on the relationship between the department, faculty, and host organization.

7. The host organization offers the training and gains no immediate advantage from the intern`s activities. Occasionally, the operations may be obstructed.

8. The student is not necessarily entitled to a job at the end of the internship.

9. The internship is successful when the student, the department, faculty, and the host establishment all share responsibility in making it a valuable experience.

\section{BENEFITS OF INTERNSHIP}

Zopiatis (2007), Knouse and Fontenot,(2008) and Sattler,( 2011) stated that internship provides significant benefits both to the hospitality organizations and the educational institutions such as the ability to educate and mentor the next generation of hospitality industry leaders by representative job possibilities and opportunities, easy access to seasonal and inexpensive labor markets, and the chance to employ someone without any long-term 
employment obligations and legal commitments.

\section{BENEFITS TO STUDENTS}

(Holyoak,2013;Atkins ,2014; Knemeyer ,2002) mentioned that the benefits to the students are:

1. Helping the students to work in a particular area and in a professional jobs.

2. Enhance understanding of theoretical lectures knowledge which becomes clearer and more workable to the student.

3. Give the students the chance to evaluate and try a job area.

4. May pave the way for permanent employment after graduation.

5. Earning money or credit.

6. Make theoretical lectures more exciting, stimulating, and transition experience from the faculty to the work environment.

7. Grow self-confidence as they identify skills, abilities, and talents.

\section{BENEFITS TO THE FACULTY}

Maertz etal. (2014) mentioned that the benefits to the faculty are:

1. Linking education to supplement and complement theoretical lectures pedagogy.

2. Attracting more students to the faculty based on the ability to offer relevant internships and jobs.

3. Improving the faculty's position and ranking in community development.

4. Support the relationships between faculty and the community.

5. Strengthen the alumni's ties and loyalty to the faculty

\section{WORK FIELD BENEFITS}

(An Intern Project of First Coast High School \& Government \& External Affairs, 2012) stated that the benefits to the Work field are:

1. Offering students educational improvements and a link to the professional world.

2. Helping to shape a new generation highly trained and multipurpose professionals.

3. Take the advantage of temporary employees through high seasons.

4. Choosing from well-informed and skilled students. 
5. Help to produce a motivated and educated workforce.

6. Having the chance to work with students who care about their community who can teach students the skills needed for their futures. They can also employ skilled personnel who can convey new ideas.

\section{INTERNSHIPS CHALLENGES}

According to Kaseorg (2015), it is important to shed light on the barring factors of accepting interns and to investigate the challenges that may hinder students in finding internship placement as well as understanding internship supervisors' views relating this issue.

Students may feel disordered on who should organize the internships arrangements and who should be responsible for ordering their internship placement; many interns feel faculty should work for their placement (Tackett et al., 2001).

Internships provide students with their first experience in the work environment. Whether positive or negative, the impression developed during this period will affect future years spent in the profession. Trainees' negative experiences during an internship will weaken their plans to work in the hospitality sector (Kasli and Ilban, 2013).

Weisz and Smith (2005) stated that one of the many internships challenges related to the increasing number of contributors industry associates were keen to take part in an internship but were not care about the detailed pedagogical methods or requirements (Bukaliya 2012(.

Knemeyer and Murphy (2002) added that the lack of orientation and stimulation of the virtual intern student. Wherever Alberto and Cabanes, (2013) confirmed that the lack of communication between the intern's employer and the student intern's educator about his performance to confirm that the student intern's training activities in the required level.

The most influence challenges and barriers of internships faced by the student is the stress of a theoretical syllabus that prevent their integration in real industry (Speight,2013).

Quaidoo et al. (2013) challenge associated with unpaid internships could minimize the chances of demand for those who care about financial means and leave behind students who are unable to work for free, leading lessening their chances to build stronger job prospects. 


\section{RESEARCH METHODOLOGY}

\section{RESEARCH CONCEPTUAL FRAMEWORK}

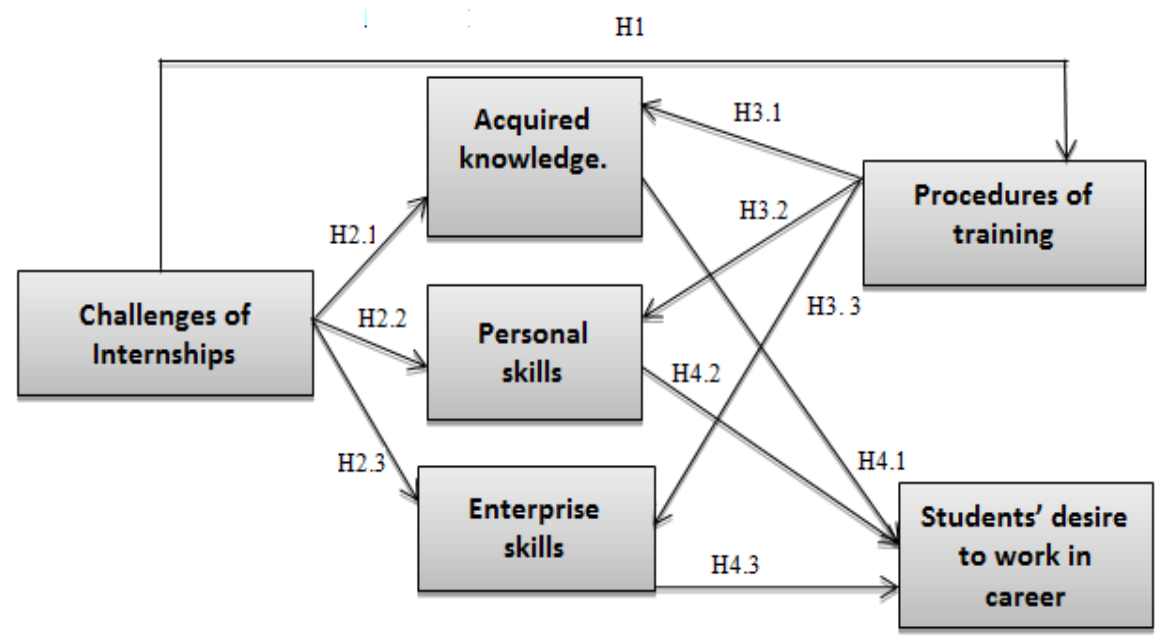

Figure (1)The Suggested Research Conceptual Framework and Hypotheses Development

Building upon the literature review, the proposed research model of this research conceptualizes the causal relationships among challenges of student training agenda and procedures of student training, and the effect of these two variables on the three following dimension acquired knowledge, personal skills, and enterprise skills and their influence on students' desire to work in hospitality career (Figure 1).

From the previous suggested figure, the following hypotheses were formulated:

H1. Challenges of training have a negative effect on procedures of training $\mathrm{H} 2$.1. The challenges of training have a negative impact on acquired knowledge.

$\mathrm{H}$ 2.2. Challenges of training have a negative impact on personal skills $\mathrm{H} 2.3$. Challenges of training have a negative impact on enterprise skills H3.1.procedures of training are positively affecting acquired knowledge H3.2.procedures of training are positively affecting personal skills H3.3.procedures of training are positively affecting enterprise skills H4.1. acquired knowledge has a positive effect on the students' desire to work in a career

H4.2. personal skills have a positive effect on the students' desire to work in a career 
H4.3. enterprise skills have a positive effect on the students' desire to work in a career

\section{Data Collection Instrument}

The primary data was collected through an online questionnaire to cover the students in all eight governmental faculties of tourism and hotels (according to the ministry of scientific research and higher education in (2018). The students of the third and fourth grades were targeted for this research especially tourism studies and hotel studies departments as those departments are the only that train students according to their internal regulations.

The questionnaire is developed based on the literature review. The form consists of five-point Likert scale statements, ranging from (1=Strongly Disagree, 2= Disagree, 3=Neutral, 4= Agree, and 5=Strongly Agree).

The online questionnaire is divided into five main sections; the first section is student data which contain ( 7 statements), while the second section is to evaluate the current role of tourism and hotel faculties toward students internship agenda, which contain (13 statements). And the third section under the title of assessment of current internships training students agenda and contains (22 statements divided into three parts, 3 statements as academic skills, 10 statements as personal skills, and 9 statements as enterprise skills). Additionally, the fourth section contains 8 statements to measure the benefits of internships to students. And the last section is internships challenges (11 statements: challenges of faculties of tourism and hotels and 7 statements: Training institutions challenges )

The questionnaire was piloted on 30 students 15 from the hotel studies department and 15 from the tourism studies department and statistics showed an evident construct validity and reliable measurement.

\section{Population AND SAMPLing}

There are Nine governmental faculties of tourism and hotels in Egypt according to official records registered in the ministry of scientific research and higher education in (2017:2018) so the students of the third and fourth grade were targeted to be a research population specifically tourism studies and hotel studies departments as those departments are the only departments that train students according to their internal regulations. And the number of these students is nearly 2694, according to the students ' affairs section at these faculties see table (1). 
Table (1): The number of students of the third and fourth grade

\begin{tabular}{|c|c|c|c|c|}
\hline $\begin{array}{c}\text { University } \\
\text { Name }\end{array}$ & $\begin{array}{l}\text { Third grade- } \\
\text { hotel studies }\end{array}$ & $\begin{array}{c}\text { Third grade } \\
\text { - tourism } \\
\text { studies }\end{array}$ & $\begin{array}{c}\text { Fourth } \\
\text { grade- hotel } \\
\text { studies }\end{array}$ & $\begin{array}{c}\text { Fourth grade/ } \\
\text { tourism } \\
\text { studies }\end{array}$ \\
\hline $\begin{array}{l}\text { Helwan } \\
\text { University }\end{array}$ & 55 & 44 & 60 & 88 \\
\hline $\begin{array}{l}\text { Alexandria } \\
\text { University }\end{array}$ & 60 & 80 & 90 & 100 \\
\hline $\begin{array}{l}\text { Fayoum } \\
\text { University }\end{array}$ & 39 & 61 & 44 & 66 \\
\hline $\begin{array}{l}\text { Suez Canal } \\
\text { University }\end{array}$ & 51 & 87 & 70 & 84 \\
\hline $\begin{array}{l}\text { Minya } \\
\text { University }\end{array}$ & 68 & 96 & 68 & 110 \\
\hline $\begin{array}{l}\text { Sadat City } \\
\text { University }\end{array}$ & 78 & 87 & 75 & 94 \\
\hline $\begin{array}{l}\text { Mansoura } \\
\text { University }\end{array}$ & 89 & 105 & 143 & 150 \\
\hline $\begin{array}{l}\text { Luxor } \\
\text { University }\end{array}$ & 66 & 64 & 55 & 70 \\
\hline $\begin{array}{l}\text { Banisweif } \\
\text { University }\end{array}$ & 22 & 77 & 32 & 66 \\
\hline
\end{tabular}

\section{Source: students ' affairs section at faculties}

So, a convenience sample was taken by distributing (450) questionnaire forms electronically by allocating (50) questionnaires for each faculty, and this number is statistically acceptable due to the size of the population. Only (330) forms were retrieved from all faculties with a response rate (73.3\%). Data was collected from June to September 2018. A deductive quantitative approach was used to test the hypotheses of the study.

\section{Data Analysis Technique}

The descriptive analysis percentages, means, standard deviation, and regression were calculated. Then, Multiple Linear Regression was calculated to determine how groups differed significantly from each other, and to recognize the correlation between variables. Therefore, reliability analysis was carried out to measure the results reliability of the questionnaire, SPSS (version 26) software was used in the analysis. Reliability tests were conducted to test the internal validity of the measurement scales. Cronbach's alphas of all constructs are greater than .7 , representing acceptable reliability. 


\section{FINDINGS}

Table (1) depicts that $55.2 \%$ of respondents were females versus $44.8 \%$ of males, $52.2 \%$ of responses are studying at the Hotel Studies Department and $47.8 \%$ are studying at Tourism Studies Department. Respondents belong to eight public universities in Egypt, with a majority of respondents belong to Fayoum University (26.9\%), Alexandria University (14.9\%), Helwan University (13.4\%), South-Valley University (10.4\%) and the rest of universities contribute with less than $10 \%$ of respondents. Places of training according to respondents are tourism companies (36.8\%), hotels $(31.8 \%)$, resorts $(12.4 \%)$, and restaurants $(10 \%)$, in addition to airline companies, catering institutes, and ministries. Periods of training range from single-day training to a year. The majority of respondents have spent 2 months (40.8\%), a month (33.3\%), three months (13.4\%).

Table (2): Descriptive statistics

\begin{tabular}{|c|c|c|c|}
\hline & $\mathrm{N}=\mathbf{2 0 1}$ & Frequency & Percent \\
\hline \multirow{9}{*}{ University } & Helwan University & 27 & 13.4 \\
\hline & Alexandria University & 30 & 14.9 \\
\hline & Fayoum University & 54 & 26.9 \\
\hline & Suez Canal University & 16 & 8.0 \\
\hline & Minia University & 19 & 9.5 \\
\hline & Sadat City University & 15 & 7.5 \\
\hline & Mansoura University & 19 & 9.5 \\
\hline & South-Valley University & 21 & 10.4 \\
\hline & Bani Sweif University & 36 & 11.5 \\
\hline \multirow[t]{2}{*}{ Department } & Hotel Studies & 105 & 52.2 \\
\hline & Tourism Studies & 96 & 47.8 \\
\hline \multirow{7}{*}{ Training place } & Hotels & 64 & 31.8 \\
\hline & Resorts & 25 & 12.4 \\
\hline & Restaurants & 20 & 10.0 \\
\hline & Catering Institutes & 2 & 1.0 \\
\hline & Tourism Companies & 74 & 36.8 \\
\hline & Airline companies & 14 & 7.0 \\
\hline & Ministries & 2 & 1.0 \\
\hline
\end{tabular}




\begin{tabular}{|c|c|c|c|}
\hline \multirow[t]{2}{*}{ Gender } & Male & 90 & 44.8 \\
\hline & Female & 111 & 55.2 \\
\hline \multirow{8}{*}{ Training period } & Day & 9 & 4.5 \\
\hline & Week & 4 & 2.0 \\
\hline & Month & 67 & 33.3 \\
\hline & 2 months & 82 & 40.8 \\
\hline & 3 months & 27 & 13.4 \\
\hline & 4 months & 2 & 1.0 \\
\hline & 6 months & 2 & 1.0 \\
\hline & Year & 8 & 4.0 \\
\hline
\end{tabular}

Table (3): Procedures of training

\begin{tabular}{|c|c|c|c|}
\hline Procedures of training & Mean & $\begin{array}{c}\text { Std. } \\
\text { Deviation }\end{array}$ & $\begin{array}{c}\text { Cronbach's } \\
\text { alpha }\end{array}$ \\
\hline $\begin{array}{l}\text { I knew where the training } \\
\text { allocated. }\end{array}$ & 2.92 & 1.734 & \multirow{9}{*}{.986} \\
\hline $\begin{array}{l}\text { I had a training agenda with } \\
\text { specific training objectives }\end{array}$ & 2.86 & 1.682 & \\
\hline $\begin{array}{l}\text { I knew which training } \\
\text { program will receive. }\end{array}$ & 2.82 & 1.670 & \\
\hline $\begin{array}{l}\text { I knew the timetable of } \\
\text { training program. }\end{array}$ & 2.89 & 1.673 & \\
\hline $\begin{array}{l}\text { I received a proper job } \\
\text { orientation of training. }\end{array}$ & 2.81 & 1.681 & \\
\hline $\begin{array}{l}\text { I knew the academic skills } \\
\text { and experience I should } \\
\text { acquire. }\end{array}$ & 2.88 & 1.694 & \\
\hline $\begin{array}{l}\text { I knew the appropriate } \\
\text { uniform for the training job. }\end{array}$ & 2.75 & 1.658 & \\
\hline $\begin{array}{l}\text { I am assigned a faculty } \\
\text { supervisor }\end{array}$ & 2.64 & 1.647 & \\
\hline I offered a log sheet to host & 2.73 & 1.621 & \\
\hline
\end{tabular}




\begin{tabular}{|l|l|l|}
\hline organization with duties & & \\
\hline $\begin{array}{l}\text { The log sheets are signed by } \\
\text { the host organization } \\
\text { supervisor }\end{array}$ & 2.78 & 1.610 \\
\hline $\begin{array}{l}\text { At the end , the host } \\
\text { organization evaluated my } \\
\text { performance }\end{array}$ & 2.73 & 1.630 \\
\hline $\begin{array}{l}\text { I wrote a training report to } \\
\text { with log sheets and } \\
\text { evaluation report }\end{array}$ & 2.71 & 1.621 \\
\hline $\begin{array}{l}\text { I received a report from the } \\
\text { faculty with the training } \\
\text { outcomes }\end{array}$ & 2.70 & 1.629 \\
\hline Mean
\end{tabular}

From table (2), it is revealed that respondents have neutral reliable responses towards procedures of training either by their faculty or the training host organizations (mean value of 2.79 and Cronbach's alpha of .986). This relates to training allocation, set training objectives, timetable, knowledge and skills, supervising procedures, and follow-up and evaluation reports. These results reflect the defect in training procedures taken by faculties and training host organizations. And this result is not agreed with Carlson and Halbrooks, (2003) who mentioned that procedures of the internship should be planned and agreed in advance by all parties before the internship begins on the agreement form. Though the duration may vary from one company to the next, the school or university offering the internship credit must be involved because most schools will have a minimum number of hours of internship necessary for each credit got by the student and Mgaya and Mbekomize ( 2015)they also mentioned that on internship, each student has a faculty supervisor who is required to regularly visit the student at the place of internship to ensure that students are involved in work that is related to their academic specialization and log sheets are the monitoring tools. 
Table (4): Knowledge acquired

\begin{tabular}{|l|c|c|c|}
\hline knowledge & Mean & $\begin{array}{c}\text { Std. } \\
\text { Deviation }\end{array}$ & $\begin{array}{c}\text { Cronbach's } \\
\text { alpha }\end{array}$ \\
\hline \begin{tabular}{l|c|c|} 
I was able to apply \\
knowledge acquired to \\
practices in industry.
\end{tabular} & 2.13 & 1.690 & \\
\hline \begin{tabular}{l|c|} 
It could enhance my \\
research and project skills.
\end{tabular} & 1.99 & 1.655 & \multirow{2}{*}{.967} \\
\hline \begin{tabular}{l|l|} 
I had the opportunity to \\
aspire future career.
\end{tabular} & 1.94 & 1.671 & \\
\hline Mean & 2.02 & 1.67 & \\
\hline
\end{tabular}

From table (4) All respondents ' answers reflect the limited role of internship period in increasing the knowledge skills of the students. This is illustrated by mean value of 2.02, and Cronbach's alpha of .967. This gives a general impression that the knowledge skills acquired by students during their internship period were below the required level, whether it is about the extent to which knowledge is applied in practice or student opportunity to aspire for progress in his future career. This result is not agreed with Holyoak (2013), Atkins (2014), Knemeyer (2002) who states that internship should help the students to work in professional environment and enhance knowledge which become clearer and more practically to the student. And the student should be able to evaluate and try a career field and making classroom learning more interesting, stimulating and transition experience from the university to the work environment. Also grow selfconfidence as they identify skills, abilities and talents

Table (5): Personal skills

\begin{tabular}{|l|c|c|c|}
\hline Personal skills & Mean & $\begin{array}{c}\text { Std. } \\
\text { Deviation }\end{array}$ & $\begin{array}{c}\text { Cronbach's } \\
\text { alpha }\end{array}$ \\
\hline \begin{tabular}{l|c|c|} 
It could support me in \\
working independently.
\end{tabular} & 3.14 & 1.695 & \\
\hline $\begin{array}{l}\text { It help me learn to } \\
\text { handle responsibility } \\
\text { and use my time wisely }\end{array}$ & 3.15 & 1.697 & \multirow{2}{*}{.991} \\
\hline $\begin{array}{l}\text { It developed my self- } \\
\text { confidence. }\end{array}$ & 2.16 & 1.702 & \\
\hline
\end{tabular}




\begin{tabular}{|l|c|c|}
\hline \begin{tabular}{l|l|} 
It could develop my \\
social interaction skills.
\end{tabular} & 3.09 & 1.675 \\
\hline \begin{tabular}{l|l|} 
It could develop my \\
oral communication and \\
presentation skills.
\end{tabular} & 3.11 & 1.665 \\
\hline \begin{tabular}{l|l|} 
It could enhance my \\
creativity.
\end{tabular} & 1.99 & 1.605 \\
\hline $\begin{array}{l}\text { It helped me dealing } \\
\text { effectively with } \\
\text { conflict. }\end{array}$ & 3.01 & 1.620 \\
\hline $\begin{array}{l}\text { It helped me develop } \\
\text { decision-making and } \\
\text { problem-solving skills }\end{array}$ & 2.97 & 1.603 \\
\hline $\begin{array}{l}\text { It could develop my } \\
\text { critical thinking skills. }\end{array}$ & 2.96 & 1.601 \\
\hline $\begin{array}{l}\text { Provided a chance to } \\
\text { use leadership. }\end{array}$ & 1.95 & 1.604 \\
\hline Mean & 2.75 & 1.65 \\
\hline
\end{tabular}

With regard to personal skills and the extent to which students acquire these skills during the internship time, the Students' answers reflect the extent to which they are weak or poorly acquired, because the mean value was (2.75), and Cronbach's alpha of .991). This relates to student personal skills Such as working independently, handle responsibility, selfconfidence, social interaction, oral communication, presentation skills, creativity, decision-making, problem-solving skills, critical thinking, and leadership. These results illustrate the student's weak acquisition of the majority of personal skills during internship period, which is one of the most important skills of tourism and hotel student that may help student in his professional career. This result is not agreed with $\mathrm{Fu}(1999)$ who mentioned that hospitality education is designed to educate people gaining the professional knowledge and skills to enter the hospitality industry and provide opportunities for experience in practical application for students to integrate their skills and knowledge and enhancing skills and update their knowledge in order to get used to the student to work enthusiastically and in a team, move quickly, solving customer and co-worker problems and keep pace with the customer expectations. Therefore, to some, stepping back into industry is a highly desired learning opportunity according to Kimberly and Zhao (2004). 
Table (6): Enterprise skills

\begin{tabular}{|c|c|c|c|}
\hline Enterprise skills & Mean & $\begin{array}{c}\text { Std. } \\
\text { Deviation }\end{array}$ & $\begin{array}{c}\text { Cronbach's } \\
\text { alpha }\end{array}$ \\
\hline $\begin{array}{l}\text { I am able to develop team } \\
\text { working skills. }\end{array}$ & 3.11 & 1.677 & \multirow{10}{*}{.980} \\
\hline $\begin{array}{l}\text { It helps me developing new } \\
\text { interests and abilities. }\end{array}$ & 3.14 & 1.682 & \\
\hline I acquired industry work culture. & 2.11 & 1.671 & \\
\hline $\begin{array}{l}\text { I could effectively prioritize } \\
\text { tasks. }\end{array}$ & 2.00 & 1.619 & \\
\hline $\begin{array}{l}\text { I'm able to develop managerial } \\
\text { skills. }\end{array}$ & 3.00 & 1.620 & \\
\hline $\begin{array}{l}\text { It enabled me to appreciate the } \\
\text { social responsibility. }\end{array}$ & 3.08 & 1.650 & \\
\hline $\begin{array}{l}\text { I feel I have better prepared to } \\
\text { work market }\end{array}$ & 2.12 & 1.639 & \\
\hline $\begin{array}{l}\text { Expanded my knowledge about } \\
\text { the work environment }\end{array}$ & 3.10 & 1.649 & \\
\hline $\begin{array}{l}\text { It provided me with contacts for } \\
\text { future employment }\end{array}$ & 3.03 & 1.634 & \\
\hline Mean & 2.74 & 1.65 & \\
\hline
\end{tabular}

From table (6), it is revealed that respondents have disagreed reliable responses regarding enterprise skills (mean value of 2.74, and Cronbach's alpha of .980). This relates to developing team working skills, developing new interests and abilities, work culture, effectively prioritized tasks, developing managerial skills, appreciating the social responsibility, preparing student to working field and contacts chance for future employment. These results reflect the defect in Enterprise skills taken by students during internship period. Which is not agreed with Felicen et' 1 (2014) who stated that the industry and academe should be integrated. In the context of reducing the gap between the industry need and the knowledge and skills provided by the educational establishment.

Kuh(2008)and Stirling et 1 (2014) also mentioned that the connection and integrating between classrooms learning and real-practical experience in the workplace has been recognized as a vital component of student engagement and development in higher. 
Table (7): Desire to work in career

\begin{tabular}{|l|l|l|l|}
\hline Desire to work & Mean & $\begin{array}{c}\text { Std. } \\
\text { Deviation }\end{array}$ & $\begin{array}{c}\text { Cronbach's } \\
\text { alpha }\end{array}$ \\
\hline $\begin{array}{l}\text { Can help me in the future to } \\
\text { work in career }\end{array}$ & 4.60 & 1.021 & \\
\hline $\begin{array}{l}\text { Enhance understanding of } \\
\text { realistic expectations in } \\
\text { workplace. }\end{array}$ & 4.62 & 1.003 & \\
\hline $\begin{array}{l}\text { Make classroom learning more } \\
\text { interesting and transition } \\
\text { experience from the university } \\
\text { to the work environment. }\end{array}$ & 4.55 & 1.072 & \\
\hline $\begin{array}{l}\text { Provide the student career } \\
\text { awareness. }\end{array}$ & 4.62 & 1.028 & \\
\hline $\begin{array}{l}\text { Give me the chance to } \\
\text { evaluate, reflect upon and try a } \\
\text { career field. }\end{array}$ & 4.64 & .966 & \\
\hline $\begin{array}{l}\text { May pave me the way for full- } \\
\text { time employment upon } \\
\text { graduation. }\end{array}$ & 4.58 & 1.017 & \\
\hline $\begin{array}{l}\text { May help me to earn money or } \\
\text { credit. }\end{array}$ & 4.50 & 1.091 & \\
\hline $\begin{array}{l}\text { Help me to build miscellaneous } \\
\text { skill sets for work }\end{array}$ & 4.65 & .963 & \\
\hline Mean & 4.6 & 1.02 & \\
\hline
\end{tabular}

The answers of the respondents indicate their agreement to the importance of the internship program (mean value of 4.6, and Cronbach's alpha of 968). This demonstrates the full agreement of the respondents to the importance of the internship program in the current student's life or in the future career, this is due to the fact that it is a main tool in preparing the students for the professional job market. It also provides the students with the ways for full-time employment upon graduation. And this agreed with (Kuh, 2008and Stirling et'l 2014) who stated that the connection and integrating between classrooms learning and real-practical experience in the workplace has been recognized as a vital component of student 
engagement and development in higher education so, one of the ways in which students may build their learning in the classroom with professional experiences is widely labeled as student internships

Table (8): Challenges and obstacles to the efficiency of student internship programs

\begin{tabular}{|c|c|c|c|}
\hline Challenges & Mean & $\begin{array}{c}\text { Std. } \\
\text { Deviation }\end{array}$ & $\begin{array}{c}\text { Cronbach's } \\
\text { alpha }\end{array}$ \\
\hline $\begin{array}{l}\text { The Faculty does not play its role } \\
\text { in internships training }\end{array}$ & 4.14 & 1.336 & \multirow{10}{*}{.972} \\
\hline $\begin{array}{l}\text { Faculty didn't coordinate the } \\
\text { internships arrangements }\end{array}$ & 4.15 & 1.367 & \\
\hline $\begin{array}{l}\text { Industry partners were not keen to } \\
\text { participate }\end{array}$ & 4.13 & 1.324 & \\
\hline $\begin{array}{l}\text { The pressures of academic work } \\
\text { undress participation in industry } \\
\text { engagement. }\end{array}$ & 4.22 & 1.286 & \\
\hline $\begin{array}{l}\text { The lack of communication } \\
\text { between the training institution and } \\
\text { faculty }\end{array}$ & 4.23 & 1.307 & \\
\hline $\begin{array}{l}\text { Lack of interest of academic } \\
\text { institutions to follow up students } \\
\text { during the internships period. }\end{array}$ & 4.22 & 1.308 & \\
\hline $\begin{array}{l}\text { Most specialized portals virtual } \\
\text { internships resources are not free } \\
\text { and in the case they are free the } \\
\text { quality is poor. }\end{array}$ & 4.26 & 1.231 & \\
\hline $\begin{array}{l}\text { Limited time allocated for } \\
\text { internships program }\end{array}$ & 4.39 & 1.174 & \\
\hline $\begin{array}{l}\text { Facilities of the tourism and hotels } \\
\text { do not include more practical side } \\
\text { in its curricula and courses. }\end{array}$ & 4.36 & 1.175 & \\
\hline $\begin{array}{l}\text { Lack of interest of faculties to } \\
\text { develop internships program }\end{array}$ & 4.23 & 1.268 & \\
\hline
\end{tabular}




\begin{tabular}{|l|l|l|}
\hline $\begin{array}{l}\text { Lack of interest of faculties to put } \\
\text { suitable intended training outcomes } \\
\text { of internships program. }\end{array}$ & 4.24 & 1.258 \\
\hline $\begin{array}{l}\text { Most of the high quality } \\
\text { internships places do not train } \\
\text { students for free }\end{array}$ & 4.12 & 1.273 \\
\hline $\begin{array}{l}\text { Lack of interest of internships } \\
\text { institutions to follow-up and } \\
\text { evaluate students }\end{array}$ & 4.24 & 1.226 \\
\hline $\begin{array}{l}\text { Far distances between internships } \\
\text { places and educations institutes. }\end{array}$ & 4.35 & 1.153 \\
\hline $\begin{array}{l}\text { Training institution does not } \\
\text { determine the duties and } \\
\text { responsibilities of the student } \\
\text { during the internships }\end{array}$ & 4.21 & 1.315 \\
\hline $\begin{array}{l}\text { Lack of tourism and hospitality } \\
\text { professional techniques and skills } \\
\text { in Training institutions }\end{array}$ & 4.27 & 1.216 \\
\hline $\begin{array}{l}\text { Internships institutions do not } \\
\text { motivate students properly }\end{array}$ & 4.39 & 1.170 \\
\hline $\begin{array}{l}\text { Internships institutions assigns } \\
\text { internships program to poor } \\
\text { persons in skills and competence }\end{array}$ & 4.28 & 1.267 \\
\hline Mean & 4.25 & \\
\hline
\end{tabular}

From table (9), it is revealed that respondents have agreed on reliable responses towards the existing challenges and obstacles to the efficiency of student internship programs, whether these challenges related to tourism and hotels faculties or related to internship institutions (mean value of 4.25, and Cronbach's alpha of .972) These results reflect the defect in internship programs taken by faculties and internship host organizations due to these great challenges.

Internship faces many challenges mentioned by Kaseorg(2015), Tackett et al.,( 2001), Kasli and Ilban (2013), Weisz, and Smith (2005),.(Alberto and Cabanes., 2013), (Speight,2013), Knemeyer and Murphy (2002) ..(Dahl,2011), Quaidoo et"l (2013) who stated that it is important to pay attention to the barring factors of accepting interns and to examine 
problems that students have in finding internship placement as well as understand internship supervisors' opinions on the matter. As lack of chances is reducing students demand and the limited number of virtual internships offered by an individual host organization which increases the cost of choosing the right student by the faculty as In most specialized portals virtual internships resources are not free and are in the case they are free the quality is not good.

\section{REGRESSION MODEL AND HYPOTHESES TESTING}

The study has four main hypotheses and some sub-hypotheses to measure the relationship between challenges of internship and procedures (H1), challenges of internship and knowledge and skills acquired (H2), procedures of training and knowledge and skills acquired (H3), and knowledge and skills acquired and desire to work in tourism and hotel career (H4).

From table (7), $\mathrm{H} 1$ is supported and challenges of internship have a negative effect on procedures of training $(\beta=-0.699, p<0.01$ and $R 2=0.22)$. $\mathrm{H} 2$ is also supported; challenges have a negative impact on: acquired knowledge $(\beta=-0.157, \mathrm{p}<0.05)(\mathrm{H} 2.1)$, personal skills $(\beta=-0.194, \mathrm{p}<0.01)$, and enterprise skills $(\beta=-0.101, \mathrm{p}<0.05)$.

Also, procedures of the internship were found positively affecting acquired knowledge and skills and H3 is supported. It is revealed that procedures are positively affecting acquired knowledge $(\beta=0.853, p<0.01)$ (H3.1), personal skills $(\beta=0.728, \mathrm{p}<0.01)(\mathrm{H} 3.2)$, and enterprise skills $(\beta=0.814, \mathrm{p}<0.01)(\mathrm{H} 3.3)$.

Furthermore, acquired knowledge and skills have a significant positive effect on students' desire to work in tourism and hospitality careers (H4). It is found that acquired knowledge has a positive effect on the desire to work in a career $(\beta=0.212, p<0.05)(\mathrm{H} 4.1)$, personal skills have a positive effect on the desire to work in a career $(\beta=0.289, \mathrm{p}<0.01)(\mathrm{H} 4.2)$, and enterprise skills have a positive effect on the career working desire $(\beta=0.223, \mathrm{p}<0.05)(\mathrm{H} 4.3)$.

Challenges explain $22 \%$ of negative impact on procedures, challenges and procedures explain $72 \%$ of the variance in acquired knowledge, $58 \%$ of the variance in personal skills, and $64 \%$ of the variance in enterprise skills. Also, acquired knowledge and skills explain $50 \%$ of the variance in the desire to work in a career based on R-square values. 
International Journal of Tourism and Hospitality Management Volume 3, Issue 2, December 2020

Table (9): Linear regression models and hypotheses testing

\begin{tabular}{|c|c|c|c|c|c|c|c|}
\hline Model & variables & B & $\begin{array}{l}\text { Std. } \\
\text { Error }\end{array}$ & $\mathbf{T}$ & Sig. & $\mathbf{R}^{2}$ & Hypothesis \\
\hline \multirow{2}{*}{1} & Constant & 5.755 & .403 & 14.272 & .000 & \multirow{2}{*}{.22} & \multirow[b]{2}{*}{ H1 Supported } \\
\hline & Challenges & -.699 & .092 & -7.581 & .000 & & \\
\hline \multirow{5}{*}{2} & Constant & 1.456 & .367 & 3.970 & .000 & \multirow{5}{*}{.72} & \\
\hline & Challenges & -.157 & .067 & -2.345 & .020 & & $\mathrm{H} 2.1$ \\
\hline & & & & & & & Supported \\
\hline & Procedures & .835 & .045 & 18.437 & .000 & & H3.1 \\
\hline & & & & & & & Supported \\
\hline \multirow{5}{*}{3} & Constant & 1.973 & .442 & 4.469 & .000 & \multirow{5}{*}{.58} & \\
\hline & Challenges & -.194 & .081 & -2.403 & .017 & & $\mathrm{H} 2.2$ \\
\hline & & & & & & & Supported \\
\hline & Procedures & .728 & .055 & 13.341 & .000 & & H3. 2 \\
\hline & & & & & & & Supported \\
\hline \multirow{5}{*}{4} & Constant & 1.354 & .415 & 3.265 & .001 & \multirow{5}{*}{.64} & \\
\hline & Challenges & -.101 & .076 & -1.333 & .041 & & $\mathrm{H} 2.3$ \\
\hline & & & & & & & Supported \\
\hline & Procedures & .814 & .051 & 15.888 & .000 & & H3.3 \\
\hline & & & & & & & Supported \\
\hline \multirow{7}{*}{5} & Constant & 1.425 & .182 & 7.838 & .000 & \multirow{7}{*}{.50} & \\
\hline & knowledge & 212 & 096 & 2.204 & .029 & & $\mathrm{H} 4.1$ \\
\hline & & .212 & . & & & & Supported \\
\hline & Personal & & & 2.914 & .004 & & H4.2 \\
\hline & skills & .289 & .099 & & & & Supported \\
\hline & Enterprise & 223 & 100 & 2.227 & .027 & & $\mathrm{H} 4.3$ \\
\hline & skills & .223 & .100 & & & & Supported \\
\hline 1 & \multirow{3}{*}{\multicolumn{7}{|c|}{$\begin{array}{l}\text { Dependent variable: procedures of training } \\
\text { Dependent variable: knowledge/ academic skills } \\
\text { Dependent variable: personal skills }\end{array}$}} \\
\hline 2 & & & & & & & \\
\hline 3 & & & & & & & \\
\hline 5 & \multicolumn{7}{|c|}{ Dependent variable: desire to work in career } \\
\hline
\end{tabular}


From the previous table, for the first hypothesis, the alternative hypothesis was accepted and the null hypothesis was rejected. Regarding the second hypothesis and its subs, the alternative hypothesis was also accepted while the null hypothesis was rejected. For the third and fourth hypotheses, the same result is reinforced as the alternative hypothesis was accepted while the null was rejected.

\section{RECOMMENDATIONS AND FURTHER STUDY}

\section{FirSTLY: FACULTIES OF TOURISM AND HOTELS}

1. Faculties of tourism and hotels should include more workable sides in its curricula and courses.

2. Faculties of the tourism and hotels should determine internships place and agenda with specific training objectives to put suitable intended training outcomes of internships program.

3. Faculties of the tourism and hotels should determine more internships period for the student and eliminate the pressures of academic courses to acquire student skills and workable experience.

4. Faculties of the tourism and hotels should coordinate the internship arrangements with industry partners long enough.

5. Faculties of the tourism and hotels should appoint a supervisor to be responsible for the students during the internships period.

6. Faculty-student supervisors have to keep good communication with the internship institution to know progress achieved by the student during the internship period.

7. Faculties of the tourism and hotels have to follow up and evaluation of the students during the internships period.

8. Faculties of tourism and hotels have to evaluate the internships program periodically to stand on the most important skills that the student needs to develop

\section{SECONDLY: TRAINING INSTITUTIONS}

1. Internship places should train students for free and with the level of the required quality.

2. Training institutions should be well versed in the practical aspects so that students can receive the skills they need.

3. Providing free transportation for students from internships places and educations institutes. 
4. Training institutions have to determine the duties and responsibilities of the student during the internship period.

5. Internship institutions have to motivate students properly, which increases the loyalty and productivity of students during internships.

6. Internships institutions have to follow-up and evaluate students during the internships period and collaborate with the educational institutions to inform them of the student's level during the internship period.

\section{THIRDLY: STUDENT RECOMMENDATIONS}

1- Students must abide by the conditions and rules of the internship without prejudice because of its importance for their careers.

2- Students must coordinate with faculties regarding internship arrangements and procedures to know the place, date and conditions of the internship, before long enough.

3- The students should evaluate the internship program in order to find out the most important skills they are acquired during this internship program, and also the most important skills that must be developed in the future in the next program.

4- The student must collaborate with the academic supervisor periodically to determine the level of their progress in the internship period and also know the problems facing them to solve it quickly.

5- The students should collaborate with the training places and coordinate with them in order to provide student with job opportunities in the future. 


\section{REFERENCES}

Michael Knemeyer Paul R. Murphy, (2002)."Logistics internships". International Journal of Physical Distribution \& Logistics Management, Vol. 32 Iss 2 pp. 135 - 152.

Alberto C. B., and Cabanes M., (2013)." Models and Practices of Virtual Internships outside Europe". International Journal of Advances in Management and Economics, ISSN: 22783369.

An Intern Project of First Coast High School \& Government \& External Affairs, (2012)."Internships for High School Students".

Atkins1 M.S., Strauman T. J., Cyranowski J.M., and Kolden G.G.,( 2014)." Reconceptualizing Internship Training Within the Evolving Clinical Science Training Model".Clinical Psychological Science, Vol 2(1) 46-57.

Brandon F.S, (2011)."An examination of the relationship between perceived organizational commitment and internships". University of Missouri - Columbia, ProQuest Dissertations Publishing.

Bukaliya, R., (2012). The Potential Benefits and Challenges of Internship Programmes in an ODL Institution: A case for the Zimbabwe Open University. International Journal on New Trends in Education and Their Implications January, February Volume: 3 Issue: 1 Article: 13 ISSN 1309-6249.

Career Center University of North Carolina Wilmington, (2011). "Student Internship Guide" nUNCW Career Center Division of Student Affairs. 
Carl P. Maertz Jr Philipp A. Stoeberl Jill Marks, (2014)."Building successful internships: lessons from the research for interns, schools, and employers", Career Development International, Vol. 19 Iss 1 pp. 123 - 142.

Carlson C.R. and Halbrooks M.C., (2003)."Essential Components of a Successful Internship Program". Ohio Nursery \& Landscape Association.

Charles M. J., (2012)." Tourism education from a relationship management perspective". Caribbean Curriculum Vol. 19, 145-170.

Cheong ALH, Yahya N B, Shen Q L and Yen A Y, (2013)."Internship Experience: An In-Depth Interview among Interns at a Business School of a Malaysian Private Higher Learning Institution". Procedia - Social and Behavioral Sciences, Taylor's University, Petaling Jaya, Selangor, Malaysia, 333 - 343.

Christou E.S., (1999)."Hospitality management education in Greece An exploratory study". journal of Tourism Management, Volume, Pages 683-691.

Corrales. C., (2014)."Starting an Internship Program". University Career Center, USA.

Dahl C., (2011)."Supervising academic library internships for nonLIS undergraduates". Library Management, Vol. 32 Iss 6/7 pp. $408-418$.

David Lain Kari Hadjivassiliou Antonio Corral Alza Iñigo Isusi Jacqueline O'Reilly Victoria Richards Sue Will, (2014)."Evaluating internships in terms of governance structures". European Journal of Training and Development, Vol. 38 Iss 6 pp. $588-603$. 
Donina A. and Luka I., (2014)."The compliance of tourism education with industry needs in latvia", European Journal of Tourism, Hospitality, and Recreation Special Issue, pp. 303-330.

Ellis J.(2010)." Internship Handbook", Saint Martin’s University, master of arts in counseling psychology,USA.

Felicen S. S., Rasa L. C., Sumanga J. E. and Buted D. R.,(2014)." Internship Performance of Tourism and Hospitality Students: Inputs to Improve Internship Program" , International Journal of Academic Research in Business and Social Sciences, Vol. 4, No. 6 ISSN: 2222-6990.

Fu H.W. (1999). "Attitudes of students, educators, and industry professionals towards hospitality internships". University of South Dakota, ProQuest Dissertations Publishing.

Gower R.k. ,( 2008)." Internships in Recreation, Sport and Tourism: Exploring Student Perceptions" Submitted in partial fulfillment of the requirements for the degree of Doctor of Philosophy in Recreation. Sport and Tourism in the Graduate College of the University of Illinois at UrbanaChampaign.

Holyoak L., (2013)."Are all internships beneficial learning experiences? An exploratory study". Education + Training, Vol. 55 Iss 6 pp. $573-583$.

Jauhari V., (2009)."The hospitality and tourism industry in India: conclusions and solutions". Worldwide Hospitality and Tourism Themes, Vol. 1 Iss 1 pp. 75 - 80 .

Kaseorg.M., (2015)."Participates' Reflection on Internship Program Barriers in Estonian Universities". International Journal of Teaching and Education, Vol. III (1), pp. 13-23. 
Kaşli.M and İlban.M.O. , (2013)." The Influence of Problems Faced During Internships on Interns' Views of Their Profession and Their Intention to Work in the Tourism Industry". Eurasian Journal of Educational Research, Issue 52, 79-96.

Kimberly J. Harris Jinlin Zhao, (2004)."Industry internships: feedback from participating faculty and industry executives", International Journal of Contemporary Hospitality Management, Vol. 16 Iss 7 pp. 429 - 435.

Knemeyer A. M. ,Murphy P.R., (2002)."Logistics internships". International Journal of Physical Distribution \& Logistics Management, Vol. 32 Iss 2 pp. 135 - 152

Knouse, S. B., and Fontenot, G., (2008). "Benefits of the business college internship" A research review. Journal of Employment Counseling, 45(2), 61-66.

Kobina Armoo Kate Neequaye, (2014)."Factors used by Ghanaian students in determining career options in the tourism and hospitality industry". Worldwide Hospitality and Tourism Themes. Vol. 6 Iss 2 pp. $166-178$.

Kwon B. R., (2002)." a study of the hotel supervisor's perception toward college students' work experiences" Submitted in Partial Fulfillment of the Requirements for the Master of Science Degree.The Graduate College, University of Wisconsin-Stout.

Lam T., and Ching L., (2007). "An exploratory study of an internship program: The case of Hong Kong students "Management, Volume, Pages 336-351.

Mgaya K. and Mbekomize C.,(2015)."Benefits to host organizations from participating in internship programs in Botswana". Asia-Pacific Journal of Cooperative Education, 
Volume 16, Issue 4, ISSN 1175-2882, New Zealand Association for Cooperatives Education.

Morgan, J., (2004). "From production line to drama school: Higher education for the further of tourism", International Journal of Contemporary Hospitality Management, 19, 91-99.

National Association of Colleges and Employers, (2011). "Position Statement: U.S. Internships A Definition and Criteria to Assess Opportunities And Determine the Implications for Compensation.

Quaidoo A.J., Platte L.L., Li J. and Pham E., (2013)." Unpaid journalism internships may serve as barrier to profession for low-income student ". The Princeton Summer Journal.

R.D. Merrit, (2008). "Student Internships", EBSCO Research Starters, EBSCO Publishing Inc, Mexico State University, Las Cruces ,USA.

San Diego State University, (2014). "Internship Definition and Characteristic Matrix".Career Services ,Division of Student Affairs.

Sattler, P. (2011). "Work-Integrated Learning in Ontario's Postsecondary Sector" Toronto, "Higher Education Quality Council of Ontario.

Scholz, R. W., Steiner R., Hansmann R.,(2004). "Role of Internship in Higher Education in Environmental Sciences" Journal of Research in Science Teaching Vol. 41, no. 1, pp. 24-46.

Shin Y.S, Lee K.W, Ahn J.S, and Jung J.W, (2012). "Development of Internship \& Capstone Design Integrated Program for University-Industry Collaboration", 6th International Forum on Engineering Education, Dept. of Computer Science and Engineering, Dongguk University, Seoul, Korea. 
Shoenfelt E. L. , Kottke J.L. , and Stone N. J..( 2012)." Master's and Undergraduate Industrial/ Organizational Internships: Data-Based Recommendations for Successful Experiences", Teaching of Psychology 39(2) 100-10.

Speight C., Boys J. and Boddington A., (2013). "Museums and Higher Education Working Together: Challenges and Opportunities". Ashgate Publishing, Ltd.

Stirling, A., Kerr, G., Banwell, J., MacPherson, E., Bandealy, A., and Battaglia, A., (2014). "What is an Internship? An Inventory and Analysis of "Internship" Opportunities Available to Ontario Postsecondary Students". Toronto: Higher Education Quality Council of Ontario.

Tackett, J., Wolf, F., \& Law, D. (2001). Accounting interns and their employers: Conflicting perceptions. Ohio CPA Journal, 60, 54-56.

U.S. Department of Labor Wage and Hour Division, (2010). "Internship Programs under the Fair Labor Standards Act", Washington, DC.

Wallets.D.,(2013)."Common Best Practice code for High-Quality Internships: Gateways to the Professions collaborative Forum" . published by the Trades Union Congress on behalf of the Gateways to the Professions collaborative Forum.

Weisz, M. and Smith, S., (2005). "Critical changes for successful cooperative education, in Higher education in a changing world". Proceedings of the 28th HERDSA Annual Conference, Sydney, 3-6: 605-615.

Yafang B.and Gongyong F., (2007)." A Study on Hospitality Students' Satisfaction towards their Internship: a Case from Hang Zhou, China". School of Tourism and Health, Zhejiang Forestry University, P.R.China. 
Zopiatis A., (2007)."Hospitality internships in Cyprus: a genuine academic experience or a continuing frustration?". International Journal of Contemporary Hospitality Management, Vol. 19 Iss 1 pp. $65-77$.

Zopiatis A., Theocharous A.L, (2013)."Revisiting hospitality internship practices: A holistic investigation". Journal of Hospitality, Leisure, Sport \& Tourism Education, Volume 13, Pages 33-46. 